\title{
Severe hyperkalaemia in the setting of tumour lysis syndrome
}

\author{
Timothy G Scully 지, Geoffrey R Wong, Andrew W Teh, Han S Lim
}

Cardiology department, Austin Health, Heidelberg, Victoria, Australia

\section{Correspondence to Dr Timothy G Scully: tgraemescully@gmail.com}

Accepted 24 September 2021

Check for updates

(c) BMJ Publishing Group Limited 2021. No commercial re-use. See rights and permissions. Published by BMJ.

To cite: Scully TG, Wong GR, Teh AW, et al. BMJ Case Rep 2021;14:e246184. doi:10.1136/bcr-2021246184

\section{DESCRIPTION}

A 49-year-old man with a structurally normal heart presented to the emergency department with pyelonephritis secondary to extended spectrum beta lactamase Escherichia coli, resulting in both septic shock and an acute kidney injury. He had a background history of a renal transplant for adult polycystic kidney disease complicated by BK viraemia with a baseline creatinine of $141 \mu \mathrm{mol} / \mathrm{L}$ and metastatic ampullary adenocarcinoma requiring a Whipple's procedure with right-sided native nephrectomy. His regular medications were sodium polystyrene sulfonate, trimethoprim, tacrolimus, folic acid, pantoprazole and prednisolone. There had been long-standing difficulties with controlling hyperkalaemia but no previous episodes of a potassium level recorded $>7.0 \mathrm{mmol} / \mathrm{L}$. On admission, the patient had a blood pressure of $75 / 53 \mathrm{~mm} \mathrm{Hg}$ and a heart rate of 130 beats $/ \mathrm{min}$. He was hypothermic with a temperature of $35.4^{\circ} \mathrm{C}$. His initial laboratory findings demonstrated a creatinine level of 203 $\mu \mathrm{mol} / \mathrm{L}$, a potassium level of $5.7 \mathrm{mmol} / \mathrm{L}$, a phosphate level of $1.32 \mathrm{mmol} / \mathrm{L}$, a serum calcium level of $2.24 \mathrm{mmol} / \mathrm{L}$ and a lactate level of $2.4 \mathrm{mmol} / \mathrm{L}$.

For resuscitation, the patient received $3 \mathrm{~L}$ of compound sodium lactate and intravenous meropenem. He also received a single intravenous dose of dexamethasone to cover for underlying adrenal insufficiency. He subsequently developed a broad complex tachycardia, caused by severe hyperkalaemia with a peak potassium level of $11.8 \mathrm{mmol} / \mathrm{L}$. The ECG demonstrated a rate of 142 beats/min without evidence of $\mathrm{P}$ waves and with the QRS segments resembling a sine wave (figure $1 \mathrm{~A}$ ). Two boluses of $2.2 \mathrm{mmol} / \mathrm{L}$ calcium carbonate, eight units of intravenous actrarapid and $100 \mathrm{~mL}$ of $8.4 \%$ of sodium bicarbonate were administered. This treatment resulted in progressive resolution of his ECG changes, with a corresponding potassium level of $5.0 \mathrm{mmol} / \mathrm{L}$ (figure $1 \mathrm{~B}, \mathrm{C}$ ).

The development of acute QRS widening and hypotension should prompt the consideration of life-threatening hyperkalaemia. ${ }^{12}$ Owing to the loss of $\mathrm{P}$ waves and broadening of the QRS complex, a severe hyperkalaemia can mimic ventricular tachycardia. The underlying cause of hyperkalaemiainduced wide complex tachycardia is an increase in the resting membrane potential due to inactivation of sodium channels, resulting in prolonged membrane depolarisation and a shorter repolarisation time. ${ }^{12}$ Therefore, treatment of hyperkalaemiainduced arrhythmias should be targeted at restoring the normal resting membrane gradient. Most commonly, either calcium gluconate or calcium
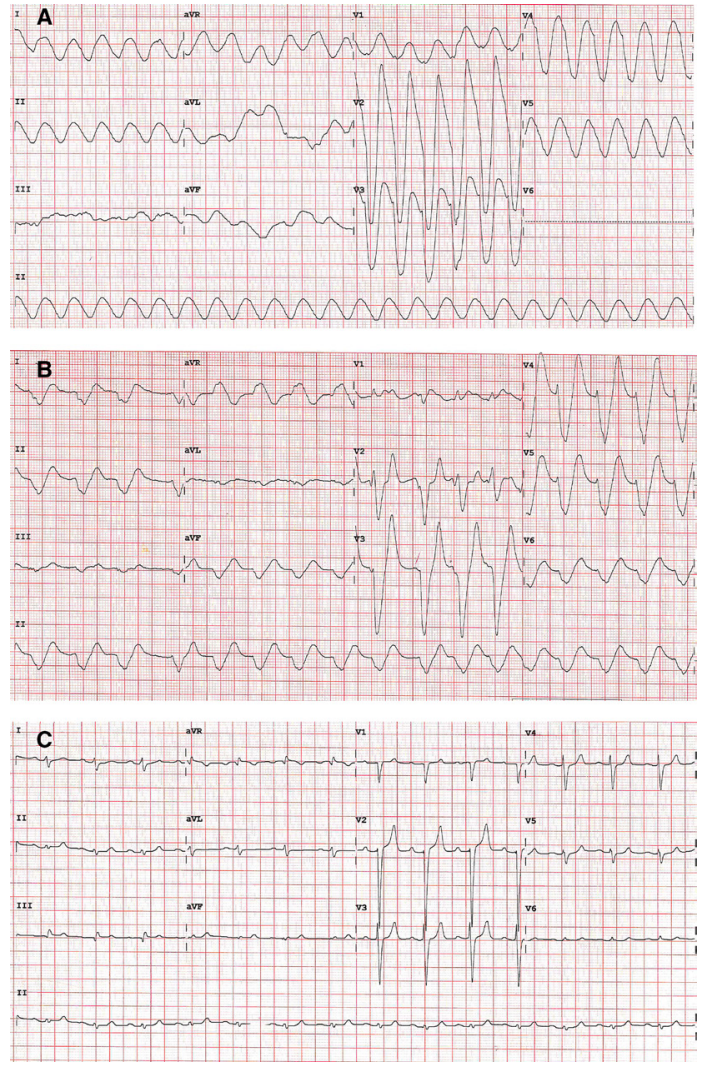

Figure 1 Progression of severe hyperkalaemia with treatment. (A) Severe hyperkalaemia (K $11.8 \mathrm{mmol} / \mathrm{L}$ ) with sine waves. (B) Broad complex QRS and peaked T waves. (C) Resolution of hyperkalaemia (K $5.0 \mathrm{mmol} / \mathrm{L}$ ).

chloride is used as these agents directly antagonise the effects of potassium on the cellular membrane. ${ }^{3}$

It is important to identify the cause of hyperkalaemia. The mechanism triggering the acute rise in potassium in this case is likely multifactorial and not entirely clear. In this case, our individual had a history of a kidney transplant with a single remaining kidney and was on both tacrolimus and trimethoprim therapy, which are known to cause hyperkalaemia. A final precipitating cause in this case was likely the administration of intravenous dexamethasone on admission to the emergency department, precipitating an episode of tumour lysis syndrome. Supporting this mechanism was the observation that 2 hours after the administration of dexamethasone, there was an increase in the serum phosphate level to $2.43 \mathrm{mmol} / \mathrm{L}$ and a fall in the serum calcium level to $1.86 \mathrm{mmol} / \mathrm{L}$. Unfortunately, no lactate dehydrogenase level or uric acid levels were obtained during the initial resuscitation stage of management. 
Although tumour lysis syndrome is usually precipitated by the administration of chemotherapy, there are numerous reports of corticosteroid therapy triggering tumour lysis syndrome. ${ }^{45}$ Although it is rarer for solid tumours such as pancreatic cancer to have tumour lysis syndrome, there are a number of risk factors for tumour lysis present in this case. ${ }^{67}$ Renal insufficiency, a rapidly growing tumour with high tumour burden, the presence of active infection and use of other medications that increase potassium all can increase the risk of tumour lysis syndrome. ${ }^{8}$

\section{Learning points}

Consideration of hyperkalaemia as an important differential in the management of broad complex tachyarrhythmias.

- Identification of medical management that may precipitate the development of hyperkalaemia in certain patient populations, including those with malignancy and underlying kidney disease.

Contributors TS and HSL conceived the initial idea. TS obtained all original images and wrote the manuscript. GRW, AWT and HSL directed the project.All contributors have reviewed the final manuscript and have approved it for submission.

Funding The authors have not declared a specific grant for this research from any funding agency in the public, commercial or not-for-profit sectors.
Competing interests None declared.

Patient consent for publication Consent obtained from next of kin.

Provenance and peer review Not commissioned; externally peer reviewed.

\section{ORCID iD}

Timothy G Scully http://orcid.org/0000-0002-1104-3511

\section{REFERENCES}

1 Mattu A, Brady WJ, Robinson DA. Electrocardiographic manifestations of hyperkalemia. Am J Emerg Med 2000;18:721-9.

2 Palmer BF, Clegg DJ. Diagnosis and treatment of hyperkalemia. Cleve Clin J Med 2017;84:934-42.

3 Weisberg LS. Management of severe hyperkalemia. Crit Care Med 2008;36:3246-51.

4 Borne E, Serafi R, Piette F, et al. Tumour lysis syndrome induced by corticosteroid in metastatic melanoma presenting with initial hyperkalemia. J Eur Acad Dermatol Venereol 2009;23:855-6.

5 Kim JO, Jun DW, Tae HJ, et al. Low-dose steroid-induced tumor lysis syndrome in a hepatocellular carcinoma patient. Clin Mol Hepatol 2015;21:85-8.

6 Saleh RR, Rodrigues J, Lee TC. A tumour lysis syndrome in a chemotherapy naive patient with metastatic pancreatic adenocarcinoma. BMJ Case Rep 2015;2015:bcr2014207748.

7 Umar J, Kalakonda A, Panebianco L, et al. Severe case of tumor lysis syndrome presenting spontaneously in a metastatic pancreatic adenocarcinoma patient. Pancreas 2017:46:e31-2.

8 Rahmani B, Patel S, Seyam 0, et al. Current understanding of tumor lysis syndrome. Hematol Oncol 2019:37:537-47.

Copyright 2021 BMJ Publishing Group. All rights reserved. For permission to reuse any of this content visit

https://www.bmj.com/company/products-services/rights-and-licensing/permissions/

BMJ Case Report Fellows may re-use this article for personal use and teaching without any further permission.

Become a Fellow of BMJ Case Reports today and you can:

- Submit as many cases as you like

- Enjoy fast sympathetic peer review and rapid publication of accepted articles

- Access all the published articles

Re-use any of the published material for personal use and teaching without further permission

Customer Service

If you have any further queries about your subscription, please contact our customer services team on +44 (0) 2071111105 or via email at support@bmj.com.

Visit casereports.bmj.com for more articles like this and to become a Fellow 